\title{
收縮性心膜炎の臨床的考察
}

神戶医科大學中院內科

友松 達彌，石川 高明，種本基一郎

安藤 武司, 藤原讓, 池 芳宸

橋本 章男, 内藤穆, 猪尾 力

\section{CLINICAL CONCIDERATION OF THE CONSTRICTIVE PERICARDITIS}

\section{BY}

Tatsuya Tomomatsu, Kōmei Ishikawa, Kiichiro Tanemoto, Takeshi Ando, Yuzuru Fujiwara, Yoshihiko Ike, Akio Hashimoto,

Kiyoshi Naito \& Tsutomu Ino

The First Department of Internal Medicine, Kobe Medical College

Clinical and laboratory studies on three cases of constrictive pericarditis were carried out in the period of time between pre- and postpericardiectomy. Two of them were restored and one died 27 days after the operation and was autopsied.

In all cases the past history supported the probable diagnosis of pericarditis of tuberculous origin. The major signs in these cases were ascites, peripheral edema, hepatosplenomegaly and engorgement of the jugulal veins.

Some manifestations like hypoproteinemia, increased sedimentation rate, elevated venous and spinal fluid pressure, low arterial blood pressure, small pulse pressure, and prolonged circulation time were in accord with those observed by many other authors.

The X-ray findings; the cardiac pulsation were definitely decreased or almost completely absent and a few plaques of calcification were found by tomography.

The electrocardiogram; flat and/or comparatively sharply or deeply inverted $T$ weves in all cases and auricular flbrillation in one case were seen but low voltage of QRS complexes was not seen in any case.

The angiocardiogram; dilatation of the superior vena cava and the small aortic arch were shown. The regurgitation of the contrast material into the inferior vena cava was also demonstrated and this is considered as a prominent sign in the diagnosis.

The liver biopsy; marked congestion was found without any change suspected of being hepatic cirrhosis.

The hemodynamic studies in the usual way by means of right heart catheterization revealed a rise of the blood pressure at any site in the range between the systemic vein and the "pulmonary capillary", and the so-called "early diastolic dip" was recorded in the right ventricle. The cardiac output was low and its level was not 
affected by the reduction of the venous return induced by the tourniquets applied on both thighs.

Dye-dilution curves obtained at the brachial arteries indicated a curve similar to normal but not a alow one as is usually seen in congestive heart failure.

The decortication of the heart improved the morbid conditions of the hemodynamics but such symptoms as peripheral edema, ascites, and hepatosplenomegaly remained unchanged, or were slightly improved.

From above studies we would like to draw the conclusion that the surgical treatment for constrictive pericarditis should be performed as soon as possible after the diagnosis has been made.

\section{緒論}

收縮性心膜炎は比較的雾てみられる疾患であり

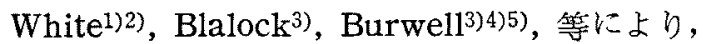
臨床及び血行動態についてすぐれた研究が報告さ れ，又1928年 Churchillが心膜剶皮術を試みて以 來，歐米に於いては Overholt, Holmann等，本 邦に於いても木本，柇原等により比較的多数の手 術例の報告檢討がなされている，我々は最近收縮 性心膜炎 3 例を経験し，そのうち2 例に就いて心 膜剥皮術前後の臨床的ならびに血行勤態に関する 觀察を行う機会を得たので，術後死亡せる他の 1 例の部檢結果をあわせ報告する。

症例 I．20才の男子，家族歴に法特記すべき のなく既往症として10才の時乾性肋膜炎に罹患， その後著変をみなかつたが激勤時には健康人に 比し呼吸困難艻烈しかつたと訴えている。

現病歴 昭和 27 年 4 月全身僚急, 腹部膨隆し, バンチ氏病の診断のもとに脾摘出, 昭和29年 1 月 発熱㺍濑右胸痛と共に顔面，下肢等に浮腫，腹部 膨隆を來たしたが 2 週間後軽快した。その後数回 同樣の症弉を繰返し昭和 30 年 3 月当内科に入院 した。

入院時現症 体格小，榮着中等，黄㾝なく，脈 拍74,整,奇脈は明らかでなく，顔面，下肢に軽度 の浮腫あり．頸部及び腹壁静脈怒張す。心濁音界 は左右共や>拡大し心音純, 腹部は膨隆し旰は右 肋骨弓下 3 横指觸知し軽度の腹水を認めた。

症例 II.19才男子，家族歴には特記すべきもの
なく, 䅡往症として昭和 26 年 6 月全身倦急, 腹部 膨隆，同年11月滲出性肋膜炎に罹患，当時心悸艺 進，腹部膨隆があつたと訴えている。

現病歴 昭和26年助膜炎に羅患後, 顔面, 下肢 の浮腫, 腹部膨隆, 心悸六進等の症狀の堌強緩解 を繰返し，昭和 30 年 8 月当内科に入院して來た。

入院時現症 体格小，やせ，チアノ一ゼなく， 脈拍78, 整なるも奇服を認め, 頸静脈, 腹壁静脈 怒張し，心濁音界正常，胸部は右背下部打診音 短, 腹部著明に膨隆し, 肝は右助骨弓下 3 横指觸 知し，脾は觸れず，腹水を認め，両下肢に浮腫を 諗めた。

症例 III.22才の男子，家族歷には同胞に肺結核 あり, 既往症として 8 才の時助膜炎に罹患し当時 腹部膨隆をみたが，以後腹部は正常人に比し大で あつた。13才の時䀒疾患に羅患した。

現病歴 昭和 26 年 7 月頃より全身倦意, 腹部膨 隆を來たし，一時軽快したが，その後も同樣症狀 を繰返し, 昭和31年 3 月上記症狀と共に心悸穴進, 呼吸困難, 顔面, 下肢の浮腫を來た七当内科に入 院した。

入院時現症 体格策養中等, 顔面胸壁四肢に浮 腫あり，軽度の黄㾝を認め，脈拍は小にして奇 脈认軽微, 頸静脈怒張し, 心濁音界柱左右共拡大 し, 心音弱, 雑音なく, 胸部背下部打診音短, 腹 部强度に膨隆し, 旰は右助骨弓下 4 横指, 脾は左 肋骨弓下 4 横指に觸知し，腹水を認めた。

手術 症例 I に於いては左右心室の全面にわた 
Table 1

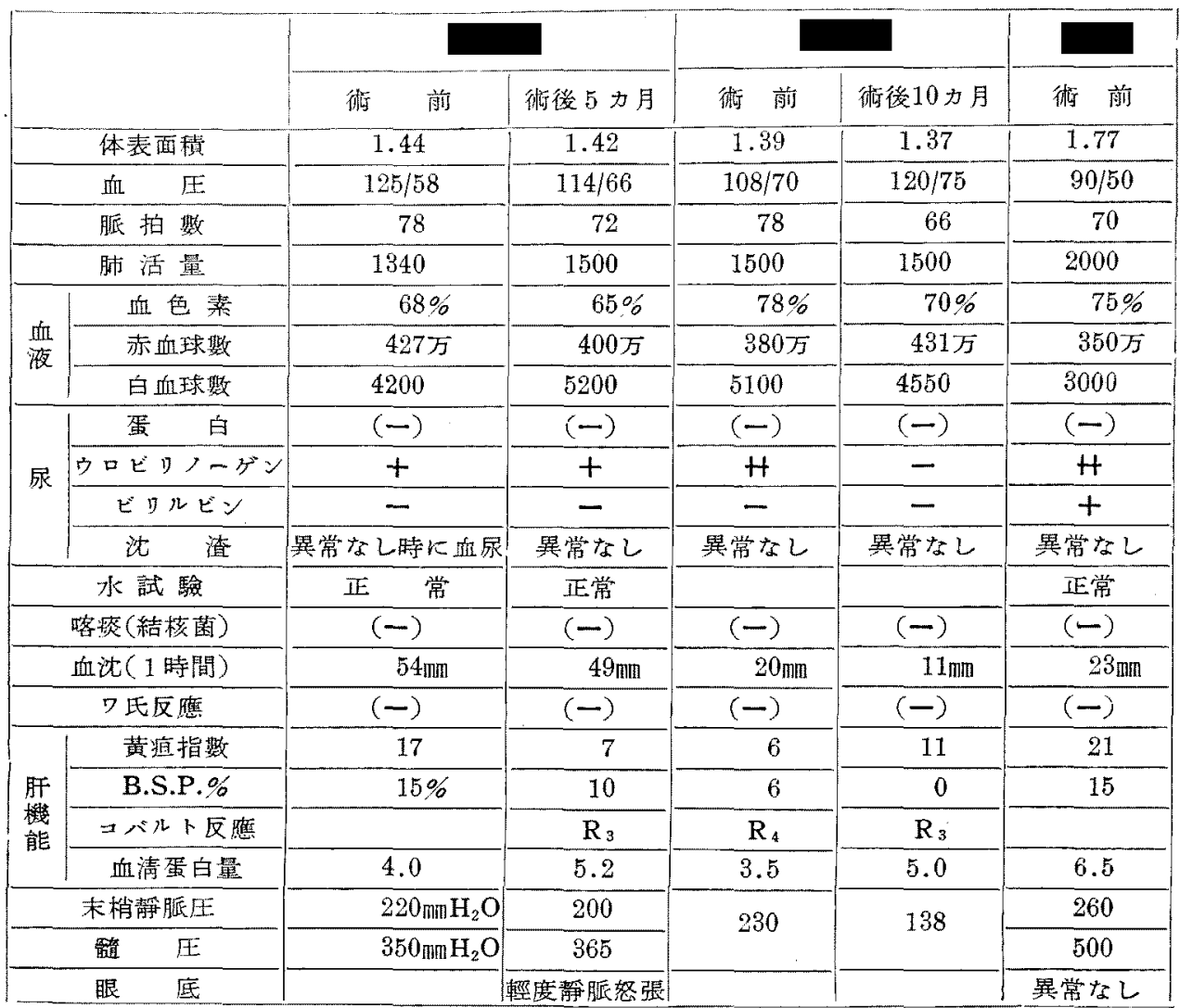

り心膜㧱皮，症例 II には右心房の前面，右心室 全面, 左心室の前，下，側壁の心膜剝皮，症例且 には左右心室の全面の心膜剥皮を行なつた。

臨床檢查成績 表 1 の如く症例 I に於いては術 前尿りロビリノーゲン軽度陽性, 赤沈值の促進, 軽 度の䀒機能障害, 脳春顝液圧の著明上暴, 循環時 間の超長がみられ，䘗後脈挡数の減少をみ，䛻環 時間は短縮した。合術後眼底静脈は軽度の怒張を 示していた。

症例 II 於いては術前軽度の貧血, 尿ウロビリ ノーゲン陽性, 赤沈值の促進, 血清蛋白量の低下 がみられ，铜後脈生の増加，尿ウロビリノーダン 正常化, 赤沈值の好転, 血清蛋白量堌加を認め, 䛻環時間は速くなつた。

症例田に於いては術前疢ウロビリノーダン，ビ
リルビン陽性, 赤沈值促進, 䀒機能障害, 䯕液圧 の著明上昇, 循環時間の延長を認めた。術後は短 期間に死亡したため，充分檢查する事が出來なか つた.

末梢静脈生は 3 例共上昇し少後倚高值を示して いた。

胸部X線像では確認出來なかつた心膜石死化像 を断層撮影に依つて全例に認め，透視上全般に心 拍動は減弱し，一部では全く拍動の認められぬ所 があり，体位変換を行なつても心藏影の変化治台 どなかつた。

心藏血管造影法では全例共上大静脈拡張し, 且 つ下大静脈域に造影剂逆流し，その拡張を示した。 特に症例 IIIでは下大静脈のみならず旰静脈迄著明 に逆流を認めた。症例 I 及びIIでは大動脈陰影は 
細以。

心電図では全例共T波の平低乃至逆転が認めら れた.

䀒穿刺標本では全例共うつ血像は离るが，硬変 像は症例 I 及びIIにはなく，症例四には軽度に認 められた。

右心カテーテル禞查では表 2 及び図 1 の如く全 例共高王值を示し，特に应張期圧及び肺毛細管压 は高値であつた，分時並びに1回心拍出量は減少 して㧍り，術後は夫々好転した。末梢静脈圧，右

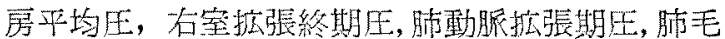
細管压に就いて術前術後走正常值と比較すると， 図 10 如く術前值は正常值よりも高く，その各部 位間の压美は少なく，術後は王は低下し正常への 近接功認められた。

右心室圧曲線は，症例 Iにおいて明ら加に $\mathrm{Ha}$ nsen等6)の云ういわゆる“early diastolic dip” 上桩镸終期の台地形成を誌めた。

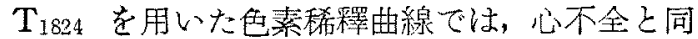
樣の臨床像を呈しているにも拘らず通常心不全に

Table 2. Results of Cardiac Catheterization

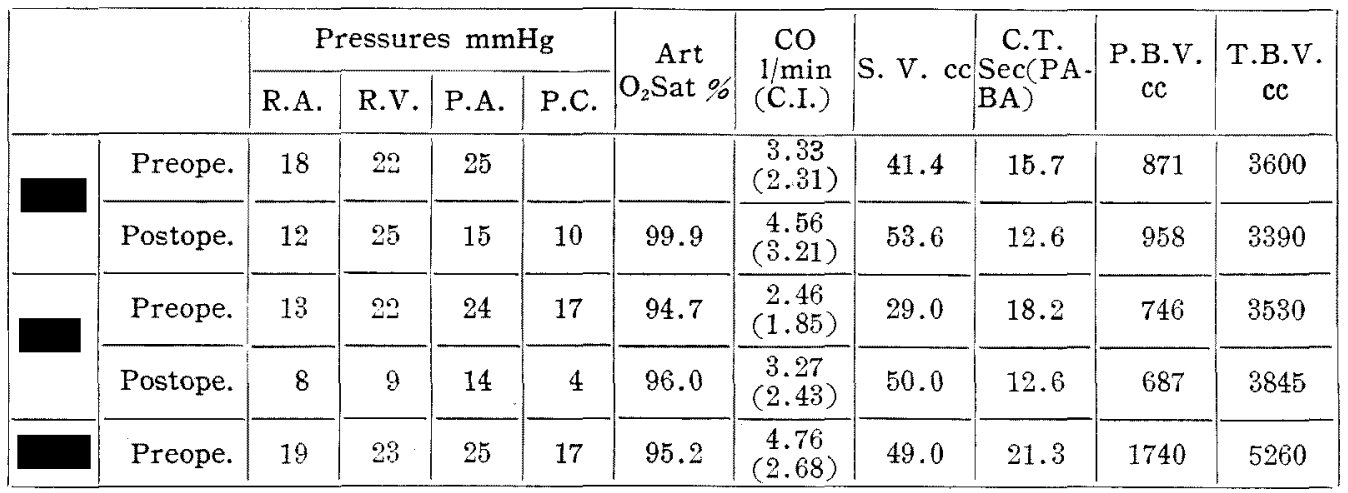

R.A.: right atrium, R.V.: right ventricle, P.A.: pulmonary artery, P.C.: pulmonary capillary, Art. $\mathrm{O}_{2}$. Sat: arterial $\mathrm{O}_{3}$ saturation, C.O: cardiac output, C.I.: cardiac index, S.V.: stroke volume, C.T. circulation time, P.A.: pulmonary artery B.A.: brachial artery, P.B.V.: pulmonary blood volume, T.B.V.:total blood volume.

Fig. 1

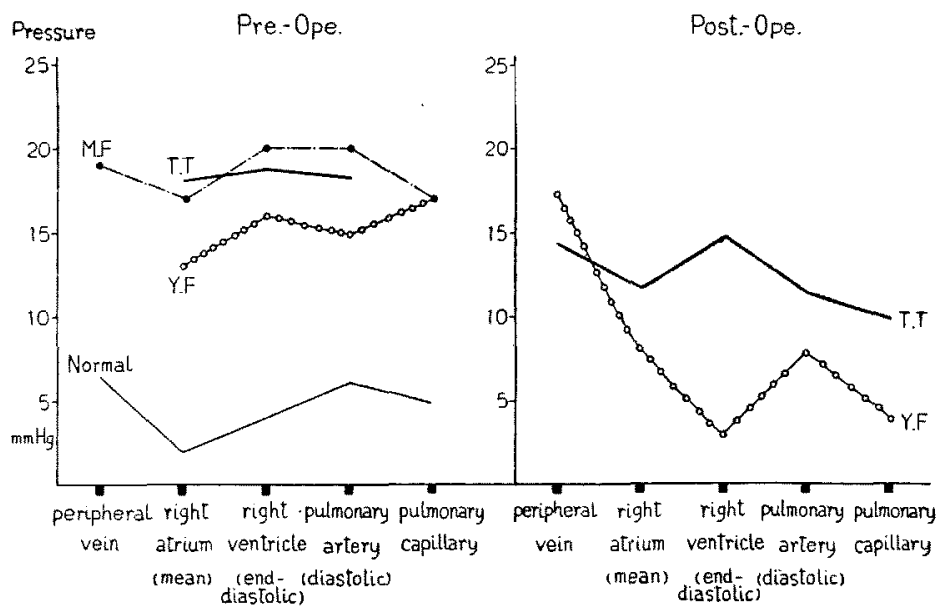


Fig. 2

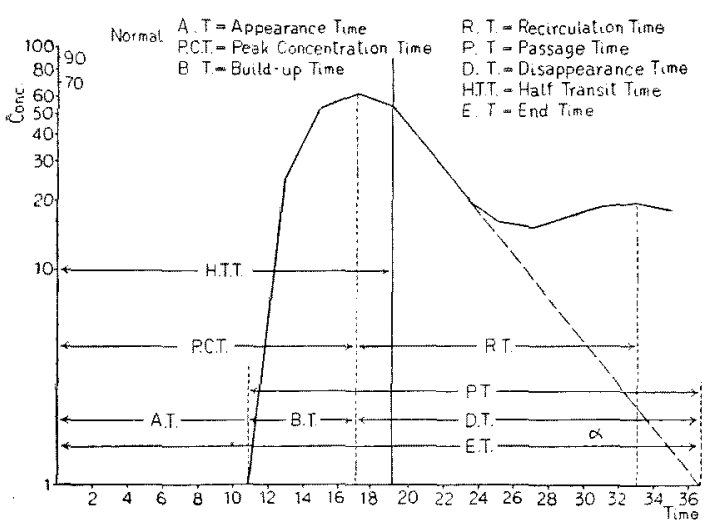

みられるような消失曲線の平低化を示すことな く，図2のごとくWood7)の色素稀釋曲線の分析を 行うと，本症例では表 4 の如く消失梋の傾斜 $\alpha$ は 正常に近い值を示した。

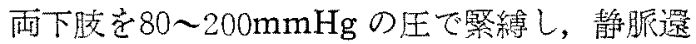
流を減少せしめると表 3 の如く正常人では㨁環時
倘淀例 III は心膜制皮術後経過上く，歩行可能迄 に回復していたが，街後27日目に突然死亡し，剖 檢の結果次の如き所見を得た。

剖检所見 心膜：著明に肥厚し $8 \mathrm{~mm}$ の厚さを有 し後部に石灰沈着高度で, 組織標本では多核白血 球，小圆形細胞，線維芽細胞，巨細胞等の浸潤も しくは増殖がある。病変は結核性と思われたが， 結核菌は証明しなかつた。

心藏：大きさ活手等大の1.4倍，瓣膜，心内膜 に变化なく右心房の腔は著明に拡張七，心筋線維 は一般に萎縮性であつた。

助膜：左全面に線維性痛着，右は瘭着なく, 胸 水約 $1200 \mathrm{cc}$.

肺：右肺中某に肺水腫を軽度に諗めた。

腹水：250cc。

䀒：2400g，うつ血著明，䀒細胞萎縮，小葉間 及び小葉内に結合織が軽度に増生，硬変の軽い彻

Table 3. Venous Congestion

\begin{tabular}{|c|c|c|c|c|c|c|c|c|}
\hline & & \multirow{2}{*}{$\begin{array}{l}\text { P.R. } \\
\text { per } \\
\text { min }\end{array}$} & \multirow{2}{*}{$\underset{\mathrm{mmH}}{\mathrm{V} \cdot \mathrm{P} .}$} & \multicolumn{2}{|c|}{ C.T. $\sec$} & \multirow{2}{*}{$\begin{array}{l}\text { C.O. } \\
1 / \mathrm{min}\end{array}$} & \multirow{2}{*}{$\begin{array}{l}\mathrm{Ht} . \\
\%\end{array}$} & \multirow{2}{*}{$\begin{array}{l}\mathrm{T} \cdot \mathrm{B} . \mathrm{V} \\
\mathrm{cc}\end{array}$} \\
\hline & & & & Dech. & T-1824 & & & \\
\hline \multirow{2}{*}{ Normal (5 cases) } & Before & 51 & 55 & 13.3 & 24.7 & 4.59 & 33.0 & 3790 \\
\hline & After & 61 & 55 & 13.5 & 19.6 & 4.16 & 33.3 & 3440 \\
\hline \multirow{2}{*}{ Cardiac } & Before & 82 & 320 & 43.0 & 64.5 & 2.92 & 25.6 & 4760 \\
\hline & After & 59 & 250 & 43.5 & 61.5 & 3.84 & 25.5 & 4620 \\
\hline \multirow{2}{*}{$\begin{array}{c}\text { Constrictive } \\
\text { Pericarditis ( } 3 \text { cases) }\end{array}$} & Before & 74 & 300 & 12.8 & 20.9 & 3.99 & 27.8 & 3420 \\
\hline & After & 80 & 250 & 12.9 & 20.2 & 3.40 & 87.6 & 3390 \\
\hline
\end{tabular}

P.R.: pulse rate, V.P.: venous pressure, C.T.: Circulation time,

C.O.: Cardiac output, T.B.V.: total blood volume.

間短縮し心拍出量及び循環血液量は減少するが， 心不全では一般に循環時間は短縮，循環血液量は 減少し，逆に心拍出量は増加する゚．然るに收縮

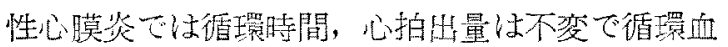
液量のみや>減少した。

以上 2 点毁方出素消失曲線の傾斜と，下胶に止 血帶裝着時の血行力学的变化は, 收樎性心膜炎に 依る心不全と，他の基磷疾患による心不全との鑑 別䛦断の一助になると思う。
期像示す, 左葉に直公 $1.5 \mathrm{~cm}$ の䀒癌あり，転移 は認められなかつた。

脾：うつ血著明で西るが線維化はなく，バンチ 氏病の所見なし。

脳：表面血管充滿や>著明で浮腫狀.

腎：特記すべき変化なし。

腹膜：旰被膜，脾被膜の一部に肥厚があるが炎 症像なし。

以上剖棎䛦断は，1）心外膜炎，2)脾の腫大，3） 
Table 4 Analysis of Dye Dilution Curve

\begin{tabular}{|c|c|c|c|c|c|c|c|c|c|}
\hline & $\begin{array}{c}\text { A.T. } \\
\text { sec }\end{array}$ & $\begin{array}{c}\text { P.C.T. } \\
\text { sec }\end{array}$ & $\begin{array}{c}\text { B.T. } \\
\text { sec }\end{array}$ & $\begin{array}{c}\text { R.T } \\
\text { sec }\end{array}$ & $\begin{array}{c}\text { P.T. } \\
\text { sec }\end{array}$ & $\begin{array}{c}\text { D.T. } \\
\text { sec }\end{array}$ & $\begin{array}{c}\text { E.T. } \\
\text { sec }\end{array}$ & $\begin{array}{c}\text { H.T.T. } \\
\text { sec }\end{array}$ & $\alpha$ \\
\hline $\begin{array}{c}\text { Normal } \\
(7 \text { cases })\end{array}$ & 7.4 & 13.0 & 5.6 & 15.5 & 27.4 & 21.8 & 54.8 & 15.0 & $390^{\circ} 06^{\prime}$ \\
\hline $\begin{array}{c}\text { Cardiac } \\
\text { Decompensation } \\
(14 \text { cases })\end{array}$ & 30.5 & 43.3 & 12.8 & & 78.1 & 65.3 & 108.6 & 50.0 & $14^{\circ} 39^{\prime}$ \\
\hline $\begin{array}{c}\text { Constrictive } \\
\text { Pericarditis } \\
\text { (3 cases) }\end{array}$ & 15.7 & 24.3 & 8.7 & 20.3 & 45.3 & 43.3 & 61.0 & 27.2 & $27^{\circ} 43^{\prime}$ \\
\hline
\end{tabular}
A.T.=Appearance Time
B.T. = Build-up Time
R.T. $=$ Recirculation Time
P.T. $=$ Passage Time
D.T. $=$ Disappearance Time
E.T. $=$ End Time
H.T.T.=Half Transit Time

P.C.T. $=$ Peak Concentration Time, $\alpha$ : Disappearance Slope

䀒腫大，4)旰癌，5)腹水，6)胸水，7)顔面皮下出 血（前額部）であつた。

\section{考按}

（Ｉ）全例共既往に急性心膜炎の時期が明確で なく，診断確定した時は暒に收縮性心膜炎の像を 呈し，バンチ氏病，心不全とまぎらわしい狀態で あった。 3 例共少反応陽性で，過去に助膜炎に霍 患し，その後徐々に症狀が進行して來たものであ り，3例共原因は結核上推定される。但し症例 II においては剖檢上心瞙に結核性变化を見たが結棌 菌を証明し得なかつた。

( II ) Burwell, Blalock, Moschcowitz ${ }^{9}$ は, 收縮性心膜炎の進行せる狀態に於ける臨床像とし て，i）静脈圧が高く且つ持続的であり，ii）收縮 期動脈圧が低く, 脈䚾減少, 奇脈，iii）頻脈，iv）

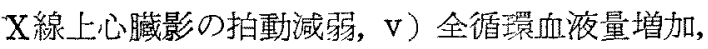
vi）循環時間延長，vii）心拍出量隇少，viii）浮 腫，腹水をあげている，我乃の症例でも上記諸症 狀を具備していたが，偱環時間の题長は軽度であ つた。向眼底静脈の怒張，髓液圧の著しい高值を 示した点は注目に值する。前川故授 ${ }^{10}$ 惊因不明 の䀒腫大は本症に注意すへき事を指摘されている 分，本症例も櫭にバンチ氏病と愦られた事があ り, 諸種䀒機能檢查成績及び相組織像には著変を みなかつた。

胸部X線上心膜石兏化像は，White ${ }^{2)}$ 等の78例 中60\%に認められているが，我乃の例では，心茞
部断層撮影を行う事により全例にこれを認める事 が出來た。

（III）心藏血管造影法において，症例 III で下大 静脈及び旰静脈に迄造影剂の迹流を認め，全例に 上下大静脈の軽度桩張を示す点隹静脈側うつ血を 意味しているが，大静脈，右房，右堂間に流大障玨 を示すべき值接的な証據は示していない，又大動

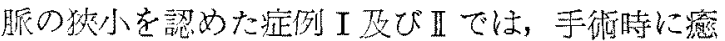
着，絞抑なき事が確吕められたが，これは恐らく は長期にわたる 1 回心拍出量の減少，血圧及び脈 生の低下によるものではないかと思う. Mckusi$\mathrm{ck}^{11)}$ は本症の䛦断を決定的にすべき特色は，心葴 血管造影法に扔いては得ることは出来ないと云う が，下大静脈領域に造影剂逆流し，特に症例正で は下大静脈のみならす肝静脈迄著明に近流を認め た点は，本症猃断上の特記すべき点と思う。

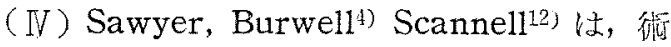
前衍後に心为テーテルを施行し，末梢静服より肺 毛細管に至る間の压高く且つ在美の少ない專を指 摘したが，我マの例でも，図1の如くこの領域に 於ける王差少なく, 高生定示し, 術後は正常值に 近接している。

（V）右心静脈力テーテル法により得た右心室 圧曲線について，“early diastolic dip”及び拡 張蔠期の台地形成については，Hansenはかっる 特異な曲線は本症に特徵的とし，診断の助けにな ると述べた.一方 low frequency artefact と 
する意見もある。これらの点に関し Bloomfield, Richards, Sawyer, Wiggers 等の報告がある. 我々の症例では症例 Iにその特徽を明睹に認め， 衍幑压出線の正常化をみたが，他の2例ではこの 所見は明らかでなかつた。

(VI) Sawyer, Burwe11 は本症の偱環不全発 生の機構につき詳しく論じている。心筋の収縮力 については心膜の炎症の波及による傷害及び線維 化が指摘され，又長期にわたる心膜の絞把により 心能の萎縮も考えられるという. 又 Cournand ${ }^{13)}$ は本症の心不全発生には心筋の要素の重要な事を 述へた。更にBurwell 等は应張期充満の障害を 重要覞している。一般に搪㲀期流满に影響する因 子として，i）拡張期の立満圧, ii) 有効な静脈還 流量, iii）拡張期時閒, iv) 心室の拡張性等が考 えられる。

我々の例について循環不全発生の要因を検討す ると，1)剖検を行なつた症例正において心筇の線 維化はなかつたが，心筋線維の萎縮及び断裂がみ られ，2)全症例においてT波が著明な变化を示し た事，3)術後除々に症状が回復した事，4)強心利 尿剂がある程度奏效した壳, 等は心筋の収縮障管 の存在を支持する。

次に色素稀圛曲線により心不全と本症患者を比 較すると，その色索稀釋曲線の消失相の傾斜は心 不全では經徐な傾斜をとるが，本症では正常に近 い傾斜をとる。この事は本症では，1心瞙の癔着 絞拒により心葴の㧨張がない事と，2)左右心室共 同じ程度に機能障害を受けている為高度の肺うつ

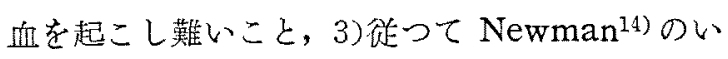
わゆる中心血液量 (Central Volume) 即方胸腔 内血液量の著增がないこと亲す。

又我々の行なつた下肢㢣縛による静脈還流減少 の血行力学的効果は本定において, 静脈圧低下, 心拍出量不变（増加しない）を示したが、これは 表 3 の如く心不全患者と異なる所見であつた。心 不全において, 表 3 の如き静脈圧の減少は, 室充 満压の低下を反映するものであつて，この際の拍 出量増加は心に対する期担の軽減分心収縮の効率
を高めたことを示すものである。然るに本症にお

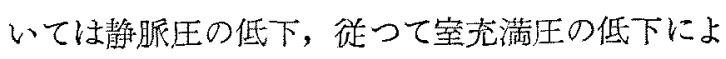
る心臓負担の軽減吕，その效率を高めないという ことである. 徒つてこれは心膜癒着收縮によっ て, 室拡張が, 言いかえれば心収縮の增大が妨げ られていると解すべきであろう，即前記色䒺稀䆁 曲線並びに還流減少実験は心膜の絞拒が及惊す重 大影響を明確に把探させるものと云える。

以上より本症に於忷る循環障害は, 心瞙絞拒に よる機棫的影響を主として，炎症に由来する心筋 障害も加わつて若起されるものと考える.

\section{結論}

1)こ〉に報告した3例の収縮性心膜咨はすへ。 て結核性と推定された。

2）先人の示した諸症状はすへて本報告例にお いて確められた。

3）診断上有意義と認めた事唡は

(i) 石灰沈着が断層撮影で容易に発見出来た $\approx \varepsilon$.

（ii）心葴血管造影法で下大静脈並びに䀒静脈 に造影剤の逆流すること。

（iii）色素稀釋曲線の消失相の傾斜が正常に近 $w=\varepsilon$.

(iv) 下肢繁縛時心拍出量の堌加を見ないこと 以上は本症に特異的と云えない点はあるが，他 の諸症狀と綜合制断するとき診断の助となる.

4）本症に起こる心不全について若干の考察を 試み，その主たる成因が絞抑による機珹的障害で あることを確めた。

5）心膜剝皮街の結果, 何軽度の浮腫, 旰腫 大，腹水を殘した。

6）外科的治痖は早期に行わなければ效果が乏 ᄂW.

（本論文の要旨は昭和31年10月27日，大阪に於け当第 2 回日本循環器學會近畿地力學會總會に扰いて發表し た. )

\section{文献}

1) Harrison, M.B., and White, P.D.: Ann. Int. Med. 17:790, 1942. - 2) Dalton, J.C., Pea- 
rson, J.R.R.J., and White, P.D.: Ann. Int. Med. 45:445, 1956. - 3) Burwell, C.S., and B1alock, A.: J.A.M.A. 110:265, 1938. -4) Saw. yer, C.G., and Burwell, C.S.: Amer. Heart J. 44:207, 1952. - 5) Burwell, C.S.: Arch. Int. Med. 56:250, 1985. -6) Hansen, A.T., Eskildsen, P., and Gotzsche, R.: Circulation 3:881, 1951. - 7) Wood,E.H., and Swan H.J.C.: J.

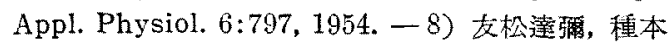
基一郎，猪尾 力：末登表. 一9) Moschcowit $z$,
E.: J.A.M.A. 158:195, 1958. - 10) 前川孫二郳: 短祭, 7:242, 1950. - 11) Mckusick, V.A.: Bu11. Johns Hopkins Hosp. 90:3, 1952. - 12) Scannell, J.G., Myers, G.S., and Friedlich, A.L.: Surgery 32:184, 195. - 18) Harvey R.M., Ferrer, M.I., Cathcart, R.T., Rickards, D.W, and Cournand, A.: Circulation 8:695, 1953. 14) Newman, E.V., Merrell, M., Genecin, A., Monge, C., Milnor, W.R., and McKeever, W.: Circulation 4:735, 1951. 